\title{
Impact of Refeeding on Intestinal Development and Function in Infant Rabbits Subjected to Protein-Energy Malnutrition
}

\author{
J. DECKER BUTZNER AND D. GRANT GALL \\ Intestinal Disease Research Unit, University of Calgary, Calgary, Alberta, Canada
}

\begin{abstract}
The impact of early postnatal protein-energy malnutrition and of 4,7 , and 14 d of nutritional rehabilitation on small intestinal growth, development, structure and function was examined in 28-, 32-, 35-, and 42-d-old infant rabbits. Malnutrition was induced by litter expansion $7 \mathrm{~d}$ postpartum and, in randomly selected malnourished animals, refeeding was begun at weaning, $28 \mathrm{~d}$. Results are compared to ad libitum fed dietary controls. Malnutrition altered the small intestine of the developing rabbit, as evidenced by: 1 ) reduced jejunal and ileal mass as shown by decreased mucosal wt, protein, and DNA content; 2) depressed epithelial proliferation and enterocyte migration along the crypt-villus axis; 3 ) delayed epithelial maturation as measured by mucosal enzyme activities; and 4) enhanced glucose-stimulated $\mathrm{Na}^{+}$transport. Refeeding stimulated rapid and complete recovery, as evidenced by: 1 ) restoration of jejunal and ileal mucosal mass within $4 \mathrm{~d} ; 2$ ) enhancement of epithelial renewal and enterocyte migration by $7 \mathrm{~d}$; and 3) complete return of the normal pattern of mucosal enzymes by $14 \mathrm{~d}$. With $7 \mathrm{~d}$ of refeeding, glucose-stimulated $\mathrm{Na}^{+}$transport was downregulated to the level of dietary controls. We conclude that early postnatal protein-energy malnutrition has a severe impact on small intestinal growth, development, structure, and function. Furthermore, a brief period refeeding induced a rapid and complete recovery of these parameters. (Pediatr Res 27: 245-251, 1990)
\end{abstract}

\section{Abbreviations}

PD, transepithelial potential difference

$I_{\text {sc }}$, short-circuit current

G, tissue conductance

$\mathbf{J}_{\mathrm{ms}}$, mucosal to serosa sodium flux

$\mathbf{J}_{\mathrm{sm}}$, serosal to mucosa sodium flux

$\mathbf{J}_{\text {net, }}$ net sodium flux

BrdU, bromodeoxyuridine

In early infancy, the small intestine undergoes a period of rapid growth and development associated with multiple alterations of intestinal structure and function. Also in the immediate postnatal period when nutrient reserves are marginal, the infant is particularly susceptible to intestinal injury. With the refeeding

July 17, 1989; accepted October 13, 1989.

Correspondence and reprint requests J. Decker Butzner, M.D., Department of Pediatrics, The University of Calgary, Health Sciences Centre, 3330 Hospital Drive, N.W. Calgary, Alberta, T2N 4N1, Canada.

Supported by the Intestinal Disease Research Unit, University of Calgary, the Canadian Foundation for lleitis and Colitis and the Medical Research Council of Canada. J.D.B. is the recipient of a clinical investigatorship award from the Alberta Heritage Foundation for Medical Research. of infants suffering from protein-energy malnutrition, clinical recovery precedes repair of the abnormalities of intestinal structure and function $(1,2)$. In some cases, intestinal damage persists for months to years after clinical recovery (3-5). This lag in recovery may be due to persistent exposure to enteric pathogens but often the cause cannot be explained.

When protein deprived adult rats are refed, epithelial cell proliferation recovers after $7 \mathrm{~d}(6,7)$ and mucosal enzyme activity returns to normal after 14-21 d (8). In malnourished infant rats, disaccharidase activities and intestinal wt recover after $14 \mathrm{~d}$ and $21 \mathrm{~d}$ of refeeding (9). Using an animal model of chronic proteinenergy malnutrition in developing infant rabbits, this laboratory demonstrated that small intestinal mass was reduced, mucosal growth impaired, maturation delayed and ileal glucose-stimulated $\mathrm{Na}^{+}$transport enhanced $(10,11)$. The aims of this study were to extend our examination of the effects of early postnatal protein-energy malnutrition on small intestinal, growth, development, structure, and function through the immediate postweaning period and to evaluate the impact of 4,7 , and $14 \mathrm{~d}$ of refeeding on the restoration of these parameters in previously malnourished infant animals. The results will provide information about the recovery of small intestinal growth, structure, and transport function after the nutritional rehabilitation of infants previously subjected to protein-energy malnutrition at a critical time in intestinal development.

\section{MATERIALS AND METHODS}

Experimental design. Does and litters of New Zealand White rabbits were quarantined at $4 \mathrm{~d}$ postpartum and observed for 3 $\mathrm{d}$ to ensure normal health and appropriate feeding behavior. Protein-energy malnutrition was induced in the experimental group by combining two litters at $7 \mathrm{~d}$ of age to increase litter size to 12 to 15 pups (mean $=14$ ). To ensure maternal health and prevent access to solid food, does were alternated at 24-h intervals. Does caged with pups had access to water only. Control litters were derived by combining two litters and then reducing litter size to six to eight animals (mean =7). As with the experimental group, does were switched daily, but access to rabbit feed was permitted throughout the study. Animals were weighed every $3 \mathrm{rd}$ d. At $28 \mathrm{~d}$ of age, randomly selected malnourished rabbits and dietary controls were killed and evaluated by the methods outlined below. The remaining animals from the control group and the malnourished group were weaned and housed individually. The malnourished group was divided in half and paired by weight. The dietary controls and half of the malnourished group were fed ad libitum. Daily weights and feed intakes were recorded. After a 12-h fast, the remaining rabbits from the malnourished group received half of the feed that their ad libitum-fed litter mate received on the previous day. All animals received water ad libitum. This resulted in five groups of animals; 1) protein-energy malnourished studied on d 28;2) control diet studied on d 28;3) control diet continued; 4) prolonged protein- 
energy malnutrition; and 5) protein-energy malnutrition and nutritional rehabilitation. Animals in the latter three groups were studied at three time periods: on d 32 (d 4 of refeeding); on d 35 (d 7 ) and on d 42 (d 14). On the day of study after a 12-h fast animals were killed by cervical dislocation and blood was collected for measurement of total protein.

The small intestine from the ligament of Treitz to the most proximal attachment of the mesoappendix was removed and unstretched segments were measured with a fixed measuring device. A 12-cm segment of the ileum ending at the mesoappendix was removed, flushed with cold isotonic saline, and used for ion transport studies. Two additional $12-\mathrm{cm}$ segments were removed; a proximal segment beginning at the ligament of Treitz and a distal segment just proximal to the segment used for transport studies. These later segments were flushed and weighed; a 2-cm segment removed for microscopic studies and mucosa scraped from the remaining $10 \mathrm{~cm}$, weighed, homogenized in $2.5 \mathrm{mM}$ EDTA $(100 \mathrm{mg} / \mathrm{mL})$ at $\mathrm{pH} 7.4$ and frozen at $-80^{\circ} \mathrm{C}$ for later estimation of mucosal enzyme activities, protein, and DNA content.

Mucosal morphology. Tissue for light microscopy was fixed in 4\% phosphate-buffered formalin, dehydrated, imbedded in paraffin wax, sectioned, and stained with hemotoxylin and eosin. Coded sections were examined by one observer without prior identification of the section. Villus height and crypt depth were measured in 10-12 properly oriented crypt-villus units per segment using a calibrated micrometer.

Mucosal enzyme activities. Homogenates were assayed for sucrase and lactase activities by the method of Dahlqvist (12), Na-K-ATPase activity by the method of Kelly et al. (13) and all expressed as $U \cdot \mathrm{cm}^{-1}$. Protein content was measured by the method of Lowry et al. (14) and DNA content by the method of Hinegardner (15) using thymus DNA (Sigma Chemical, St. Louis, MO) as a standard.

Ileal transport and electrical activities. For ion transport studies, the mucosa of the distal segment was stripped of its overlying muscle and serosa and four adjacent segments mounted in shortcircuited Ussing chambers, exposing a $0.4-\mathrm{cm}^{2}$ surface area to 10 $\mathrm{mL}$ of oxygenated Kreb's-bicarbonate buffer at $37^{\circ} \mathrm{C}$ and $\mathrm{pH} 7.4$ $\pm 0.1(16)$. Glucose $(10 \mathrm{mM})$ was added to the serosal side and mannitol $\left(10 \mathrm{mM}\right.$ ) to the mucosal side. Ten $\mu \mathrm{Ci}^{22} \mathrm{Na}$ (New England Nuclear, Montreal, Quebec, Canada) was added to either the mucosal or serosal side of each tissue segment. The spontaneous transepithelial PD was determined and the tissue clamped at zero voltage by continuously introducing an appropriate Isc with an automatic voltage clamp (DVC 1000, World Precision Instruments, New Haven, CT), except for 15-20 s every 5 min when open PD was measured. Conductance $(G)$ was calculated from PD and Isc according to Ohm's law (17). After a 15-min equilibration period, samples for $\mathrm{Na}^{+}$fluxes were obtained from the mucosal and serosal chambers at 5-min intervals for $15 \mathrm{~min}$. Immediately after completion of the basal period, glucose and mannitol (final concentration $30 \mathrm{mM}$ glucose and $10 \mathrm{mM}$ mannitol) were added to both sides of the tissue and after 15-min of equilibration, flux measurements were repeated. Tissue pairs were discarded if conductances varied by more than $30 \%$. Steady state unidirectional $J_{m s}, J_{s m}$, and $J_{\text {net }} \mathrm{Na}^{+}$fluxes $\left(\mu \mathrm{Eq} \cdot \mathrm{cm}^{-2} \cdot \mathrm{h}^{-1}\right)$ were calculated in paired tissues in the absence of an electrochemical gradient across the tissue by measuring three consecutive 5-min fluxes and one overall 15-min flux during each of the two periods.

Mucosal kinetics. Animals used to evaluate epithelial migration rates received an intraperitoneal injection of $100 \mu \mathrm{g}$ of BrdU (Sigma Chemical Corp., St. Louis, MO.) per g body wt and were killed at either 1, 33, or $53 \mathrm{~h}$ post injection. Two 2-cm segments of intestine were obtained: one $5-\mathrm{cm}$ distal to the ligament of Treitz and the second $5-\mathrm{cm}$ proximal to the mesoappendix. These were fixed in Carnoy's solution overnight, imbedded in paraffin, cut in $5 \mu \mathrm{m}$ sections and stained by the modification of the method of Wynford-Thomas and Williams (18). Sections were hydrolysed in $1 \mathrm{M} \mathrm{HCl}$ for 50 -min at $37^{\circ} \mathrm{C}$ to achieve partial denaturation to expose the antigenic determinants on DNA. Sections were treated with a 1:50 dilution of the primary antibody (anti-BrdU, Becton Dickinson Canada Inc., Mississauga, Ontario, Canada) followed by 1:100 dilution of the secondary antibody (peroxidase-conjugated goat anti-mouse IgG, Organon Teknika Corp., Scarborough, Ontario, Canada). Ten to 20 welloriented crypt-villus columns were examined per segment. The number of crypt cells per column, the height of the leading edge (highest cell to incorporate the label) and the labeling index (percentage of crypt cells incorporating the label) were determined at $1 \mathrm{~h}$. Crypt-villus column height and the distance of the foremost labeled cells from crypt base were measured at 33 and $53 \mathrm{~h}$. Migration rates were calculated and expressed as change in position of the foremost labeled cells per $h$. Only the movement of the fastest cells were scored which represents the maximum epithelial migration rate.

Data are expressed as mean \pm SEM and statistical comparisons were made using one-way analysis of variance. Mortality data were analyzed by the $\chi^{2}$ method.

\section{RESULTS}

Clinical. Initial mean body wt for the dietary groups did not differ on $\mathrm{d} 7$ when litters were combined (control $108 \pm 4 \mathrm{~g}$; malnourished $116 \pm 5$ ). After only $2 \mathrm{~d}$ of dietary restriction, at $9 \mathrm{~d}$ of age, the mean cumulative wt gain of the malnourished rabbits was significantly less than controls (Fig. 1). The differences in mean cumulative wt gain persisted for the remainder of the study. At $32 \mathrm{~d}$ of age, after $4 \mathrm{~d}$ of refeeding, the wt gain of the malnourished-refed group was significantly greater than the malnourished group and remained so until the completion of the study (Fig. 1). Although rate of wt gain of the malnourishedrefed group paralleled that of dietary controls, cumulative wt gain remained significantly less than controls throughout the period of nutritional rehabilitation (Fig. 1). Mean body wt of the malnourished and malnourished-refed group were significantly less than controls on each study day (Fig. 2). The mean body wt of the malnourished-refed group were significantly greater than the malnourished group after 7 and $14 \mathrm{~d}$ of refeeding, at 35 and $42 \mathrm{~d}$ of age. Serum total proteins were similar in all dietary groups at all ages (data not shown).

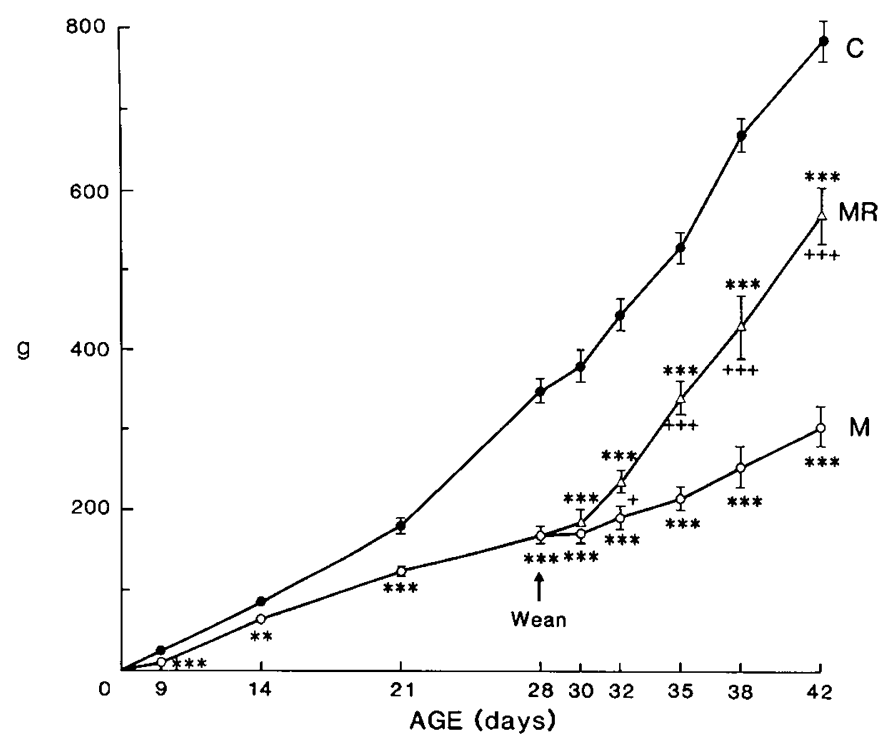

Fig. 1. Mean cumulative wt gains of rabbits in g. Animals malnourished $(M, O)$ from age $7 \mathrm{~d}$ gained less than control $(C, \bullet)$ at all time periods from $9 \mathrm{~d}$. Malnourished animals that were refed $(M R, \triangle)$ beginning on $\mathrm{d} 28$ also gained less than $\mathrm{C}$ at all time periods but more than $\mathrm{M}$ from day 32 onward $\left({ }^{* *} p<0.01,{ }^{* * *} p<0.001\right.$ comparing $\mathrm{M}$ or MR to $\mathrm{C} ;+p<0.05,+++p<0.001$ comparing MR to $\mathrm{M}$ ). 

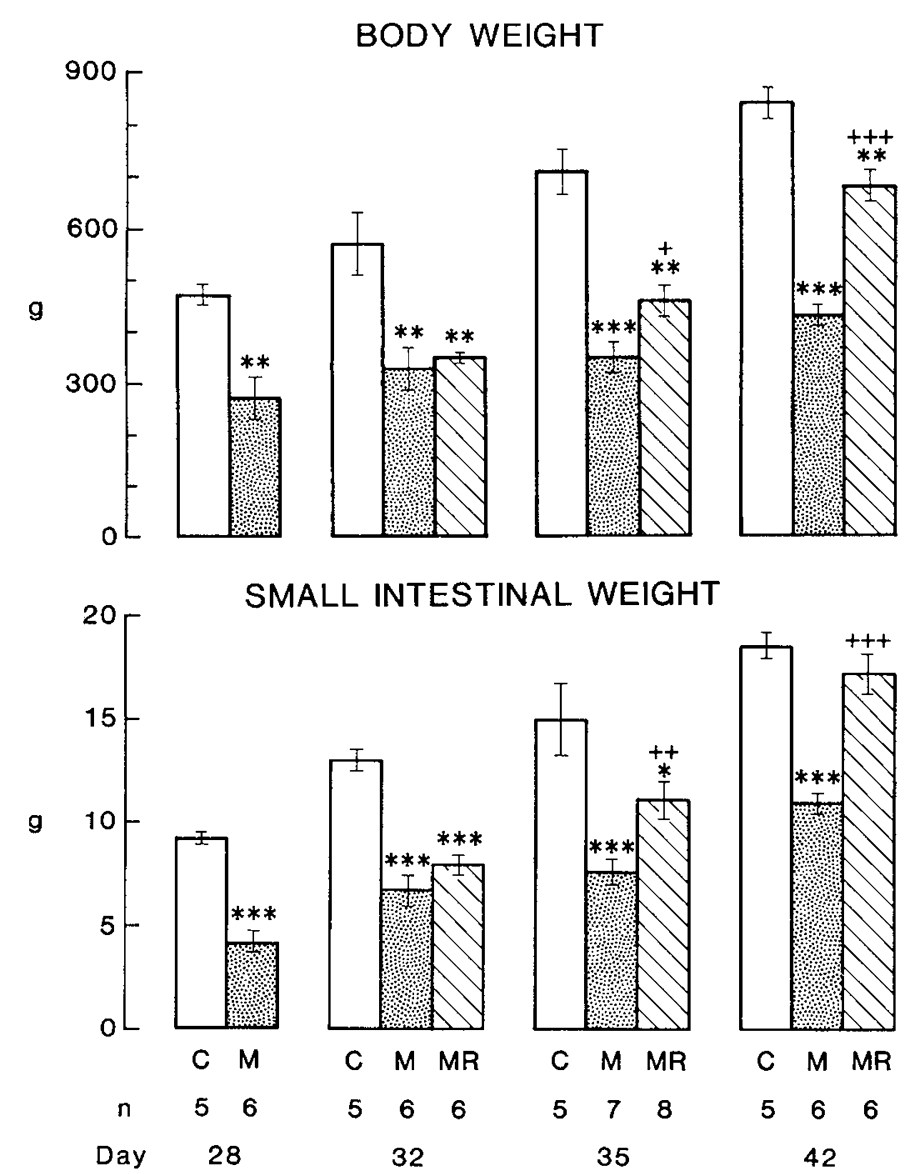

Fig. 2. Mean body and total small intestinal wt in $\mathrm{g}$ of controls $(C$, $\square)$, malnourished $(M, \square)$ and malnourished-refed $(M R, \mathbb{Q})$ rabbits at age in days, where $n$ is the number of animals ${ }^{*} p<0.05,{ }^{* *} p<0.01$, *** $p$ $<0.001$ comparing $\mathrm{M}$ or MR to $\mathrm{C} ;+p<0.05,++p<0.01,+++p<$ 0.001 comparing MR to $M$ ).

Mean daily feed intake after weaning was significantly greater $(p<0.05)$ for the malnourished-refed group $(93 \pm 8 \mathrm{mg} \cdot \mathrm{g}$ body $\left.w^{-1} \cdot \mathrm{d}^{-1}\right)$ compared to the control $(71 \pm 3)$ and the malnourished $(58 \pm 7)$ groups which did not differ significantly.

Although most animals remained clinically healthy, 11 of 75 malnourished animals and three of 34 controls died during the study. No animals developed a clinical enteric infection and none died after the initiation of refeeding. There was no difference in mortality between study groups by $\chi^{2}$ analysis.

Intestinal wt, protein, and DNA content. Total small intestinal wt of the malnourished group was significantly less than that of dietary controls at all time periods (Fig. 2). In the malnourishedrefed group, small intestinal wt became significantly greater than that of the malnourished group by $\mathrm{d} 35$, after $7 \mathrm{~d}$ of refeeding. With $14 \mathrm{~d}$ of refeeding, total small intestinal wt had recovered to the level of dietary controls. In the malnourished group, segmental jejunal and ileal mucosal wet wt, protein and DNA content were less than controls, reaching significance at all time periods with the exception of jejunal wet wt and protein at $35 \mathrm{~d}$ of age (Fig. 3). With only $4 \mathrm{~d}$ of refeeding, by d 32, segmental jejunal and ileal mucosal wet wt, protein, and DNA content had recovered to the level of dietary controls. Jejunal DNA content and ileal mucosal wt, protein, and DNA content of the malnourished-refed group were significantly greater than values for malnourished animals from $32 \mathrm{~d}$ on. Jejunal mucosal wet wt and protein content were increased after 7 and $14 \mathrm{~d}$ of refeeding compared to malnourished animals of equivalent age. Jejunal and ileal protein:DNA ratios were calculated and did not differ between dietary groups at any age of study.

Mucosal morphology (Fig. 4). In the jejunum of malnourished animals, villus ht at $28 \mathrm{~d}$ and crypt depth at 28,35 , and $42 \mathrm{~d}$ of age were significantly reduced compared to dietary controls. Ileal villus ht and crypt depth of malnourished animals were significantly decreased at 28,35 , and $42 \mathrm{~d}$ of age compared to controls. In the malnourished-refed group, villus ht in the jejunum and ileum was similar to dietary controls at all time periods, but was significantly greater than that of malnourished animals in the jejunum at $35 \mathrm{~d}$ and in the ileum at 35 and $42 \mathrm{~d}$ of age. Jejunal and ileal crypt depths in the refed group were significantly greater compared to both the malnourished and dietary control groups at 35 and $42 \mathrm{~d}$ of age. Mucosal damage was not observed at any age in any of the dietary groups.

Mucosal kinetics (Table 1). In the jejunum and ileum of 35d-old malnourished animals, enterocyte proliferation was depressed, as evidenced by a reduction in the number of cells per crypt column, the $\mathrm{ht}$ of the crypt proliferative compartment (leading edge of the label), and the percentage of crypt cells incorporating the label at $1 \mathrm{~h}$ (labeling index) compared to controls. Also in both segments of malnourished animals, migration of labeled enterocytes along the villus from the crypt was depressed 33 and $53 \mathrm{~h}$ after injection of the label compared to controls. Calculated enterocyte migration rate of the malnourished group in the jejunum was $44 \%$ and in the ileum $29 \%$ of dietary controls. In 35-d-old rabbits that had been refed for $7 \mathrm{~d}$, all parameters of epithelial renewal including the number of cells per crypt column, the leading edge of the proliferative compartment and the labeling index were significantly elevated compared to those of malnourished animals. Furthermore, in the malnourished-refed group, the number of cells per crypt column in both segments, and the leading edge of the proliferative compartment in the ileum were significantly increased compared to dietary controls. With $7 \mathrm{~d}$ of refeeding, the distance covered by migration of the first labeled cell in the jejunum at $53 \mathrm{~h}$ and in the ileum at 33 and $53 \mathrm{~h}$ after injection of the label was similar to dietary controls. Jejunal enterocyte migration remained significantly depressed at $33 \mathrm{~h}$ after injection of the label compared to dietary controls. Migration of the first labeled cell up jejunal and ileal villi was significantly greater in the malnourished-refed group compared to the malnourished group at 33 and $53 \mathrm{~h}$. The calculated migration rates in the jejunal and ileum of the malnourished-refed group recovered to 72 and $82 \%$ of dietary controls.

Mucosal enzyme activities. Associated with weaning, as expected in dietary controls, between 28 and $42 \mathrm{~d}$ of age, mucosal lactase activity decreased in both jejunum and ileum and mucosal sucrase activity increased (Fig. 5). Sucrase activity increased earlier in the jejunum than ileum. Jejunal and ileal lactase activities were significantly depressed in malnourished animals at $28 \mathrm{~d}$ of age compared to controls. In the jejunum, lactase activities were similar in all three dietary groups for the remainder of the study. However, in the ileum, whereas lactase activities declined in the control and malnourished-refed groups, they remained significantly elevated in the malnourished group at 32 and $35 \mathrm{~d}$ of age compared to dietary controls. Ileal lactase activities were similarly depressed in all three dietary groups by $42 \mathrm{~d}$ of age. In malnourished animals, jejunal sucrase activity was significantly depressed at 28, 32, and $35 \mathrm{~d}$ of age compared to controls. Ileal sucrase activity was low in both control and malnourished animals at 28 and $32 \mathrm{~d}$ of age, and remained depressed in the malnourished animals at 35 and $42 \mathrm{~d}$ of age compared to controls. In the jejunum and ileum of the malnourished-refed group, sucrase activities were similar to dietary controls at 32 and $42 \mathrm{~d}$ of age but significantly depressed at $35 \mathrm{~d}$ of age.

Na-K-ATPase activity was significantly depressed in the jejunum at $42 \mathrm{~d}$ and in the ileum at 28 and $42 \mathrm{~d}$ of age in the malnourished group compared to dietary controls. In the malnourished-refed animals Na-K-ATPase was significantly elevated compared to the malnourished group at $42 \mathrm{~d}$ of age.

Ileal sodium transport and electrical activity. Table 2 summa- 
Jejunum MUCOSAL WET WEIGHT
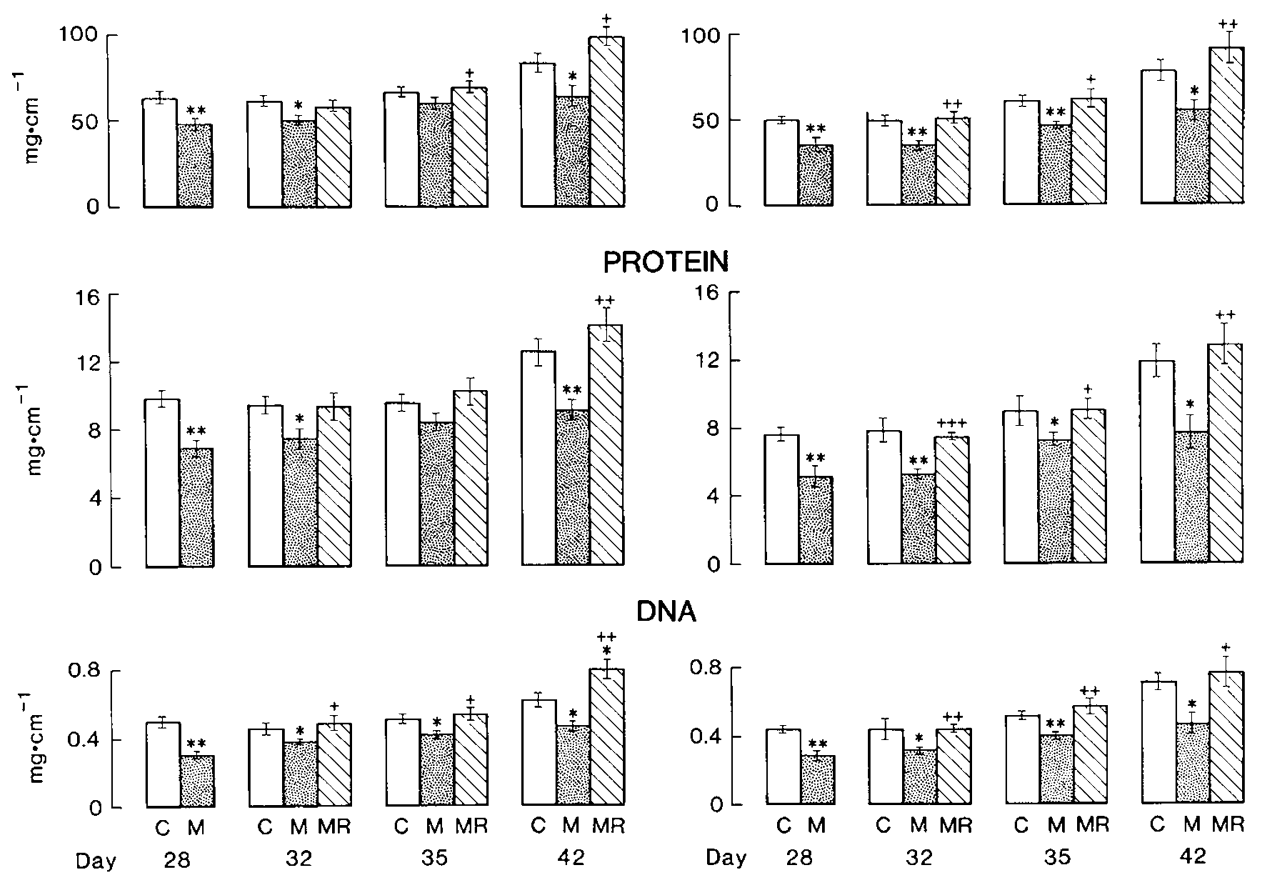

DNA

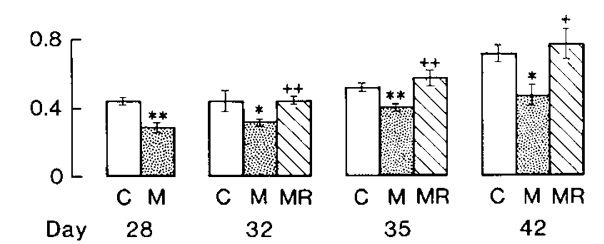

Fig. 3. Jejunal and ileal segmental mucosal wet $\mathrm{wt}$, protein, and DNA content in $\mathrm{mg} \cdot \mathrm{cm}^{-1}$. Legends and notations as in Figure 2.
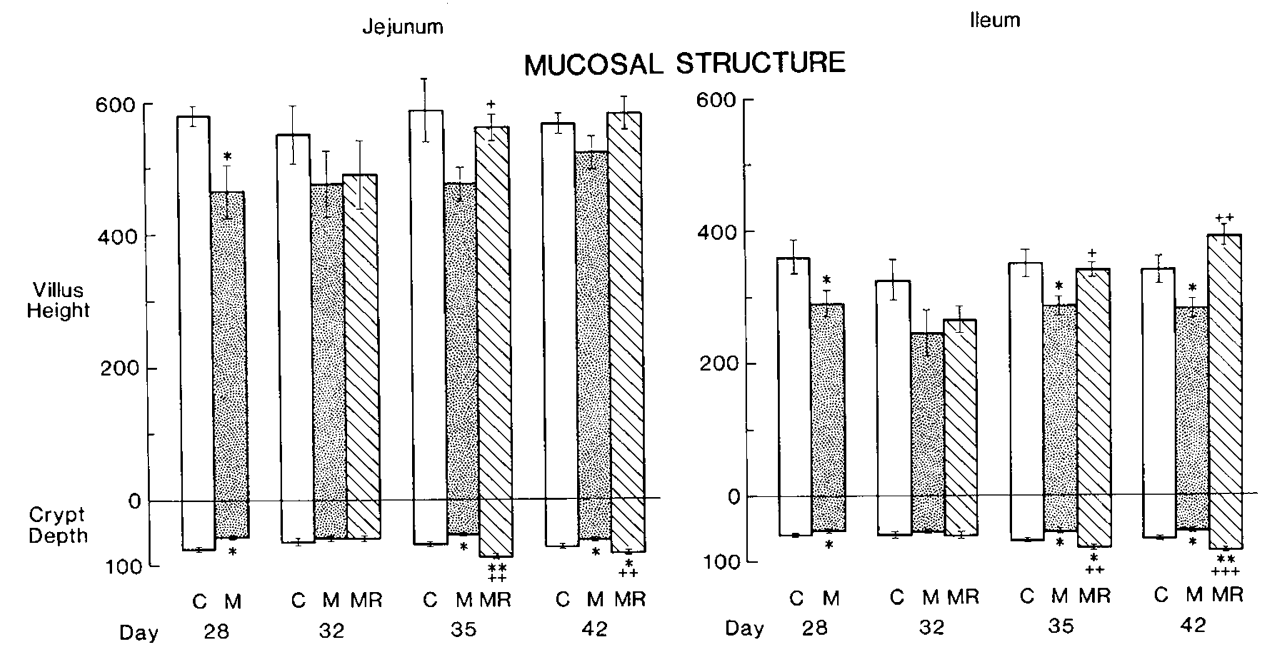

Fig. 4. Jejunal and ileal villus ht and crypt depth in $\mu$. Legends and notations as in Figure 2.

Table 1. Mucosal kinetics along jejunal and ileal villi in dietary control (C), malnourished (M), and malnourished-refed (MR) animals at $35 \mathrm{~d}$ of age*

\begin{tabular}{|c|c|c|c|c|c|c|}
\hline \multirow[b]{2}{*}{ Group $(n)$} & \multicolumn{3}{|c|}{ Jejunum } & \multicolumn{3}{|c|}{ Ileum } \\
\hline & $C(11)$ & $\mathrm{M}(9)$ & MR (10) & $\mathrm{C}$ & $\mathrm{M}$ & MR \\
\hline Crypt-villus length $(\mu)$ & $651 \pm 27$ & $544 \pm 23 \dagger$ & $641 \pm 7 \ddagger$ & $371 \pm 9$ & $331 \pm 12 \dagger$ & $366 \pm 8 \ddagger$ \\
\hline Cells/crypt column & $20.1 \pm 0.6$ & $15.6 \pm 0.4 \uparrow$ & $22.5 \pm 0.3 \dagger t$ & $15.6 \pm 0.5$ & $11.8 \pm 0.4 \dagger$ & $17.0 \pm 0.4 \dagger t$ \\
\hline Leading edge & $12.8 \pm 0.5$ & $9.0 \pm 0.4 \uparrow$ & $13.4 \pm 0.3 \ddagger$ & $9.4 \pm 0.6$ & $6.0 \pm 0.3 \dagger$ & $11.8 \pm 0.5+t$ \\
\hline Labeling index & $32.3 \pm 1.1$ & $19.0 \pm 0.6 \dagger$ & $32.4 \pm 0.7 \ddagger$ & $35.6 \pm 1.1$ & $22.6 \pm 1.1 \dagger$ & $38.3 \pm 1.3 \ddagger$ \\
\hline FLC at $33 \mathrm{~h}(\mu)$ & $141 \pm 6$ & $94 \pm 6 \dagger$ & $118 \pm 4 \dagger \ddagger$ & $127 \pm 6$ & $104 \pm 4 \dagger$ & $130 \pm 6 \ddagger$ \\
\hline FLC at $53 \mathrm{~h}(\mu)$ & $315 \pm 29$ & $171 \pm 7 \dagger$ & $244 \pm 16 \ddagger$ & $217 \pm 7$ & $130 \pm 8 \dagger$ & $204 \pm 7 \ddagger$ \\
\hline Migration rate $(\mu / \mathrm{h})$ & 8.7 & 3.8 & 6.3 & 4.5 & 1.3 & 3.7 \\
\hline
\end{tabular}

* Leading edge is the highest cell in column incorporating BrdU label and labeling index is the percentage of crypt cells incorporating label at 1 h. FLC is the distance from crypt base to foremost labeled cell at the time after labeling. Migration rate is the calculated migration between 33 and $53 \mathrm{~h}$. Values are mean \pm SEM.

$\dagger p<0.05 \mathrm{M}$ or MR compared to $\mathrm{C}, \$ p<0.05 \mathrm{MR}$ compared to $\mathrm{M}$. 

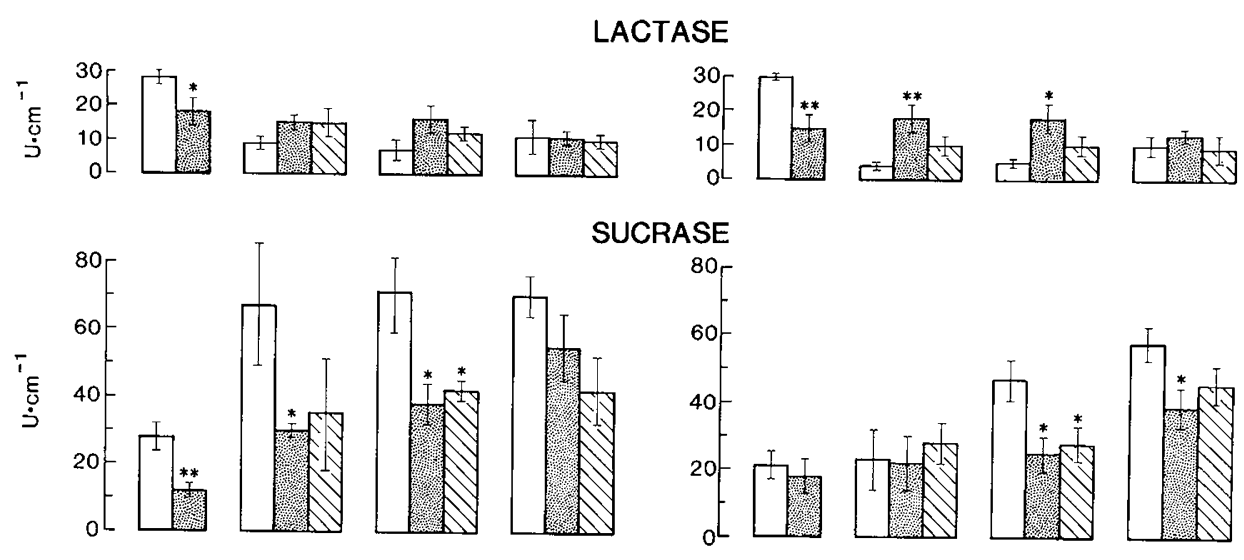

SUCRASE
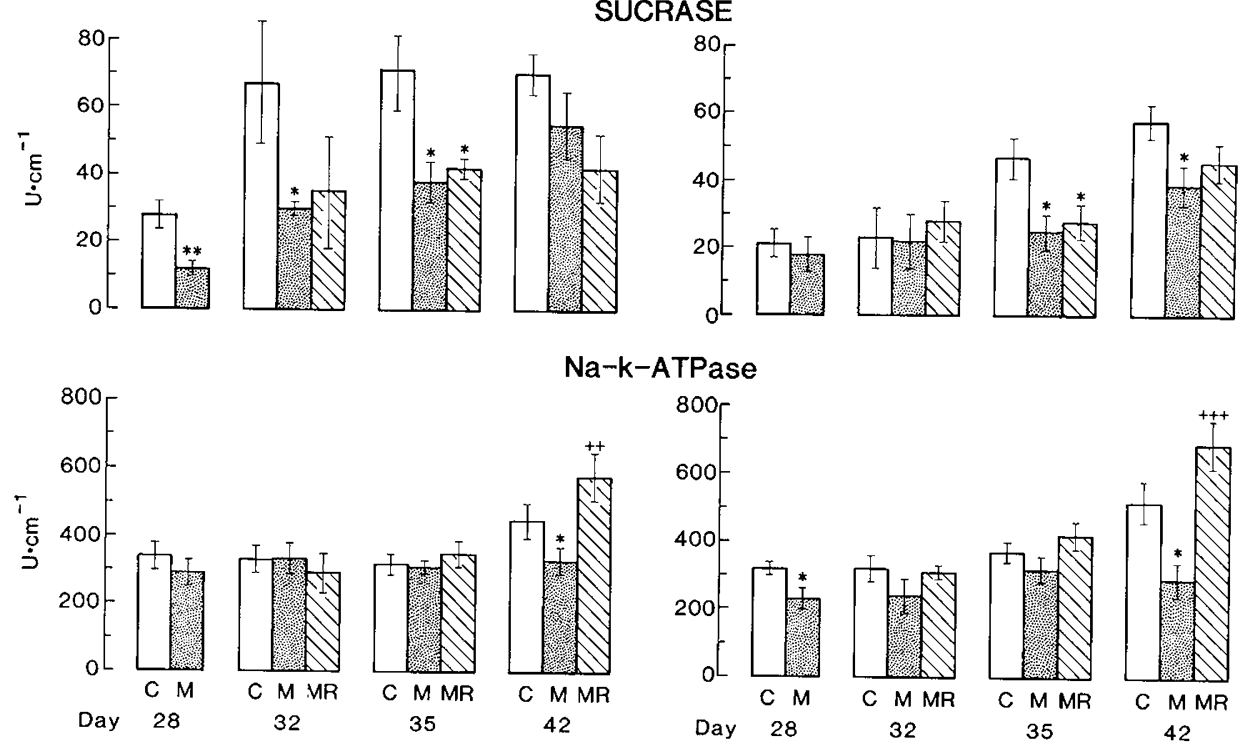

Na-k-ATPase
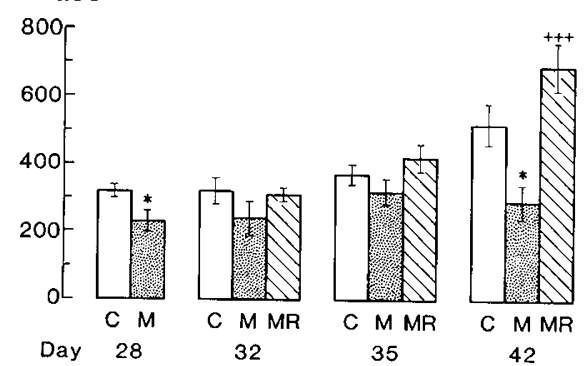

Fig. 5. Jejunal and ileal mucosal lactase, sucrase, and Na-K-ATPase activities in $\mathrm{U} \cdot \mathrm{cm}^{-1}$. Legends and notations as in Figure 2.

rizes unidirectional and net intestinal sodium fluxes as well as electrical activity for each study group measured under basal conditions and after the addition of $30 \mathrm{mM}$ glucose. In all three dietary groups at all ages, $\mathrm{J}_{\text {net }}, \mathrm{J}_{\mathrm{ms}}, \mathrm{I}_{\mathrm{sc}}$, and $\mathrm{PD}$ were significantly increased by $30 \mathrm{mM}$ glucose in ileal epithelium except for $I_{s c}$, and $P D$ in the malnourished group and $I_{s c}$ in the malnourishedrefed group at $32 \mathrm{~d}$ of age. $\mathrm{J}_{\mathrm{sm}} \mathrm{Na}^{+}$fluxes were unchanged. After glucose stimulation, $\mathrm{G}$ did not vary from basal values with the exception of a significant increase noted in malnourished animals at 28 and $35 \mathrm{~d}$ of age.

The increase in net $\mathrm{Na}^{+}$absorption $\left(\Delta \mathrm{J}_{\text {net }}\right)$ stimulated by the addition of glucose was significantly greater in the malnourished group at all ages compared to controls (Fig. 6). Enhanced glucosestimulated $\mathrm{Na}^{+}$transport was also noted in the malnourishedrefed animals at $32 \mathrm{~d}$ of age. However, as the duration of refeeding increased, 7 and $14 \mathrm{~d}$, glucose-stimulated $\mathrm{Na}^{+}$transport returned to the lower levels observed in dietary controls.

\section{DISCUSSION}

In the malnourished group, the reduction of dietary intake led to reduced wt gain within $2 \mathrm{~d}$ and resulted in mean body wt that were $56,58,49$, and $51 \%$ of dietary controls at $28,32,35$, and $42 \mathrm{~d}$ of age. This corresponds with a clinical state of severe malnutrition or marasmus, defined as body wt less than $60 \%$ of expected wt for age without edema (19). Despite this extreme degree of malnutrition, animals remained healthy and the mortality rate between dietary groups did not differ.

The impact of protein-energy malnutrition on the small intestine was severe. Total intestinal wt in the nutrient-deprived animals was reduced at each age of study. This reduction was associated with a decrease in the mucosal compartment, as evidenced by diminished mucosal wt, protein, and DNA content in both jejunal and ileal segments. On examination of morphology, villus ht, and/or crypt depth were decreased at most time periods. These observations suggest the mucosa of the malnourished infant sustains a persistent and severe reduction in the number of cells including epithelial cells. This reduction in cell number appears greater than the impact on cell size, as evidenced by the lack of variation in protein:DNA ratios between dietary groups. The findings are in keeping with previous studies performed in malnourished infant rats $(20,21)$ and rabbits $(10,11)$. Decreased epithelial proliferation and delayed enterocyte migration in jejunum and ileum of malnourished animals also indicate that inadequate nutrition impairs intestinal growth. Studies in starved adult rats $(6,7)$, malnourished infant rats (20), and suckling rabbits (10) have shown that an increased cell cycle time, a decreased enterocyte proliferative compartment or both contribute to the impairment of intestinal growth. The depressed intestinal lactase activities and jejunal sucrase activities seen in malnourished animals at $28 \mathrm{~d}$ of age provide additional evidence of mucosal hypoplasia.

Postnatal development of the small intestine of many species, including the rabbit, is characterized by marked variations in mucosal enzyme activities that occur at the time of weaning (16, 22). These changes include a fall in lactase activity and an increase in sucrase and Na-K-ATPase activities. In our longitudinal examination of intestinal dissacharidase activities, we observed a delayed fall in ileal lactase activity, as well as a late rise in jejunal and ileal sucrase activities, and no increase in Na-KATPase activity in the malnourished group. These findings confirm and extend previous observations in infant rats $(20,21)$ and rabbits $(10,11)$ that suggest that early nutrient deprivation delays postnatal maturation of enzyme activity.

Glucose, as expected, stimulated $\mathrm{Na}^{+}$absorption in ileal epithelial tissue from all dietary groups. However, glucose-stimulated $\mathrm{Na}^{+}$absorption was significantly enhanced in malnourished animals, suggesting a compensatory adaptation. Similar results were observed in the jejunum of undernourished piglets (23) and the ileum of suckling malnourished infant rabbits (11). A study on adult rats subjected to semistarvation indicates that this adaptation may be due to increased sodium and glucose uptake by the brush border membrane (24). Although mechanisms responsible for these adaptive changes remain to be defined, the findings indicate that transport capacity is increased, possibly due to a greater number of $\mathrm{Na}^{+}$-glucose cotransporters despite a decrease in mucosal mass. 
Table 2. Sodium fluxes and electrical activities in short-circuited ileal epithelium*

\begin{tabular}{|c|c|c|c|c|c|c|c|}
\hline & & $\mathrm{J}_{\mathrm{ms}}$ & $\mathbf{J}_{\mathrm{sm}}$ & $J_{\text {net }}$ & $I_{s c}$ & PD & $\mathrm{G}$ \\
\hline $\begin{array}{l}\text { A. } 28 \mathrm{~d} \\
\text { C } \\
\\
M\end{array}$ & $\begin{array}{l}\text { Basal } \\
\text { Glucose } \\
\text { Basal } \\
\text { Glucose }\end{array}$ & $\begin{array}{l}15.4 \pm 0.9 \\
19.0 \pm 0.8 \dagger \\
15.7 \pm 0.6 \\
22.2 \pm 1.0 \S\end{array}$ & $\begin{array}{l}14.4 \pm 0.7 \\
16.1 \pm 1.0 \\
15.2 \pm 0.6 \\
16.9 \pm 0.5\end{array}$ & $\begin{array}{l}+1.0 \pm 0.5 \\
+2.9 \pm 0.6 \dagger \\
+0.5 \pm 0.5 \\
+5.3 \pm 0.9 \S\end{array}$ & $\begin{array}{l}3.3 \pm 0.3 \\
5.6 \pm 0.4 \ddagger \\
2.4 \pm 0.3 \\
5.8 \pm 0.3 \S\end{array}$ & $\begin{array}{l}-2.1 \pm 0.3 \\
-3.0 \pm 0.2 \dagger \\
-2.5 \pm 0.2 \\
-3.6 \pm 0.3 \dagger\end{array}$ & $\begin{array}{l}42 \pm 3 \\
50 \pm 3 \\
38 \pm 3 \\
49 \pm 3 \dagger\end{array}$ \\
\hline $\begin{array}{l}\text { B. } 32 \mathrm{~d} \\
\mathrm{C} \\
\mathrm{M} \\
\mathrm{MR}\end{array}$ & $\begin{array}{l}\text { Basal } \\
\text { Glucose } \\
\text { Basal } \\
\text { Glucose } \\
\text { Basal } \\
\text { Glucose }\end{array}$ & $\begin{aligned} 9.4 & \pm 0.6 \\
11.6 & \pm 0.7 \dagger \\
14.1 & \pm 1.0 \\
17.9 & \pm 1.2 \dagger \\
11.2 & \pm 0.9 \\
15.2 & \pm 0.9 \ddagger\end{aligned}$ & $\begin{array}{l}10.4 \pm 0.7 \\
10.4 \pm 0.6 \\
14.8 \pm 0.5 \\
13.4 \pm 1.3 \\
11.5 \pm 0.7 \\
11.2 \pm 0.6\end{array}$ & $\begin{array}{l}-1.0 \pm 0.4 \\
+1.2 \pm 0.2 \S \\
-0.7 \pm 0.7 \\
+4.5 \pm 1.1 \ddagger \\
-0.4 \pm 0.7 \\
+4.0 \pm 0.9 \ddagger\end{array}$ & $\begin{array}{l}2.9 \pm 0.5 \\
4.3 \pm 0.3 \dagger \\
4.0 \pm 0.3 \\
4.6 \pm 0.3 \\
3.8 \pm 0.2 \\
4.9 \pm 0.4 \dagger\end{array}$ & $\begin{array}{l}-2.4 \pm 0.4 \\
-3.6 \pm 0.3 \dagger \\
-3.5 \pm 0.3 \\
-3.6 \pm 0.2 \\
-4.0 \pm 0.3 \\
-4.6 \pm 0.3\end{array}$ & $\begin{array}{l}23 \pm 1 \\
24 \pm 1 \\
33 \pm 3 \\
36 \pm 4 \\
27 \pm 2 \\
29 \pm 2\end{array}$ \\
\hline $\begin{array}{l}\text { C. } 35 \mathrm{~d} \\
\mathrm{C} \\
\mathrm{M} \\
\mathrm{MR}\end{array}$ & $\begin{array}{l}\text { Basal } \\
\text { Glucose } \\
\text { Basal } \\
\text { Glucose } \\
\text { Basal } \\
\text { Glucose }\end{array}$ & $\begin{array}{l}10.4 \pm 0.6 \\
13.2 \pm 0.9 \dagger \\
11.9 \pm 0.6 \\
18.0 \pm 0.7 \S \\
12.1 \pm 0.9 \\
15.2 \pm 0.9 \dagger\end{array}$ & $\begin{array}{l}11.5 \pm 0.5 \\
11.8 \pm 0.8 \\
12.3 \pm 0.2 \\
13.1 \pm 0.5 \\
11.6 \pm 0.5 \\
12.2 \pm 0.9\end{array}$ & $\begin{array}{l}-1.1 \pm 0.4 \\
+1.3 \pm 0.2 \ddagger \\
-0.4 \pm 0.6 \\
+4.8 \pm 0.7 \S \\
+0.5 \pm 0.4 \\
+3.0 \pm 0.5 \ddagger\end{array}$ & $\begin{array}{l}2.8 \pm 0.5 \\
4.6 \pm 0.5 \dagger \\
4.0 \pm 0.4 \\
6.9 \pm 0.5 \S \\
3.1 \pm 0.4 \\
5.1 \pm 0.6 \dagger\end{array}$ & $\begin{array}{l}-2.7 \pm 0.4 \\
-4.2 \pm 0.5 \dagger \\
-3.2 \pm 0.3 \\
-4.2 \pm 0.3 \dagger \\
-2.9 \pm 0.4 \\
-4.4 \pm 0.5 \dagger\end{array}$ & $\begin{array}{l}28 \pm 2 \\
29 \pm 2 \\
34 \pm 2 \\
43 \pm 3 \dagger \\
30 \pm 3 \\
32 \pm 3\end{array}$ \\
\hline $\begin{array}{l}\text { D. } 42 \mathrm{~d} \\
\mathrm{C} \\
\mathrm{M} \\
\mathrm{MR}\end{array}$ & $\begin{array}{l}\text { Basal } \\
\text { Glucose } \\
\text { Basal } \\
\text { Glucose } \\
\text { Basal } \\
\text { Glucose } \\
\end{array}$ & $\begin{aligned} 10.9 & \pm 0.6 \\
13.0 & \pm 0.4 \dagger \\
9.4 & \pm 0.5 \\
14.5 & \pm 1.2 \ddagger \\
10.4 & \pm 0.9 \\
13.3 & \pm 0.8 \dagger\end{aligned}$ & $\begin{array}{r}10.4 \pm 0.5 \\
10.1 \pm 0.8 \\
11.0 \pm 0.8 \\
12.0 \pm 0.7 \\
10.5 \pm 0.7 \\
9.6 \pm 0.5 \\
\end{array}$ & $\begin{array}{l}+0.5 \pm 0.6 \\
+2.9 \pm 0.8 \dagger \\
-1.5 \pm 0.7 \\
+2.5 \pm 0.7 \ddagger \\
-0.1 \pm 0.5 \\
+3.8 \pm 0.8 \ddagger\end{array}$ & $\begin{array}{l}2.1 \pm 0.2 \\
3.9 \pm 0.5 \dagger \\
3.8 \pm 0.5 \\
6.4 \pm 0.7 \dagger \\
2.8 \pm 0.3 \\
4.7 \pm 0.5 \ddagger\end{array}$ & $\begin{array}{l}-2.0 \pm 0.2 \\
-3.9 \pm 0.6 \dagger \\
-3.3 \pm 0.4 \\
-4.6 \pm 0.3 \dagger \\
-3.1 \pm 0.5 \\
-5.0 \pm 0.5 \dagger\end{array}$ & $\begin{array}{l}28 \pm 3 \\
27 \pm 2 \\
32 \pm 3 \\
36 \pm 4 \\
26 \pm 2 \\
25 \pm 2 \\
\end{array}$ \\
\hline
\end{tabular}

* Values are mean \pm SEM for dietary controls (C), malnourished (M), and malnourished-refed (MR) groups. $\mathrm{J}_{\mathrm{ms}}, \mathrm{J}_{\mathrm{sm}}, \mathrm{J}_{\mathrm{net}}$, and $\mathrm{I}_{\mathrm{sc}}$ are in $\mu \mathrm{Eq}$. $\mathrm{cm}^{-2} \cdot \mathrm{h}^{-1} ; \mathrm{PD}$ is in $\mathrm{mV}$; and $\mathrm{G}$ (tissue conductance) is in $\mathrm{mS} \cdot \mathrm{cm}^{-2}$;

$\dagger p<0.05, \ddagger p<0.01, \S p<0.001$ comparing values in the basal period to the glucose-stimulated period.

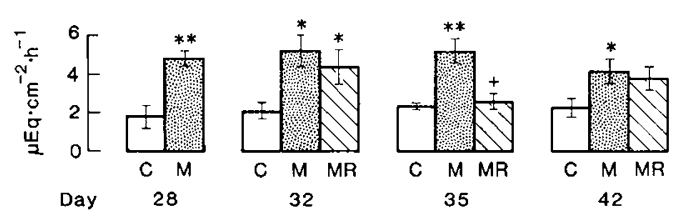

Fig. 6. Increment of $\mathrm{Na}^{+}$absorption above basal levels after the addition of $30 \mathrm{mM}$ glucose $\left(\Delta \mathrm{J}_{\text {net }}\right)$ in $\mu \mathrm{Eq} \cdot \mathrm{cm}^{-2} \cdot \mathrm{h}^{-1}$. Legends and notations as in Figure 2.

Within $4 \mathrm{~d}$ of beginning nutritional repletion, wt gain of the refed group was greater than that of litter mates subjected to persistent malnutrition. This wt gain was associated with a dietary intake that was even greater than dietary controls, when intake was based on body wt. The intestine recovered quickly with nutritional rehabilitation. Although body wt of the refed group did not return to that of the control group with $14 \mathrm{~d}$ of refeeding, small intestinal wt did. This suggests that the intestine recovers at a faster rate than the whole body after previous nutrient deprivation. The intestinal mucosa recovered even more rapidly. Jejunal and ileal mucosal wet wt, protein, and DNA content returned to levels similar to dietary controls after only 4 $\mathrm{d}$ of refeeding. Once again protein:DNA ratios did not differ between dietary groups, which suggests recovery was due to an increase in cell number rather than an increase in cell size. The increase in jejunal and ileal crypt depth, seen in the refed group at 35 and $42 \mathrm{~d}$ of age compared to both malnourished animals and dietary controls, signifies a compensatory increase in the epithelial proliferative compartment. This was confirmed by the mucosal kinetic experiments that demonstrated that epithelial renewal and enterocyte migration rates returned to control levels in the jejunum and ileum with $7 \mathrm{~d}$ of refeeding and were enhanced compared to malnourished animals. Studies in adult rats, subjected to acute starvation and subsequent refeeding, suggest that this recovery is due to a decrease in the duration of the cell renewal cycle $(6,7,25)$. Whether these events are triggered by luminal nutrients, intestinal growth factors, hormones, or neuronal stimulation remains to be determined.

In general, the delay in postnatal development of mucosal enzyme activity caused by early postnatal malnutrition recovered rapidly with the institution of adequate nutrition. Although the decrease in lactase activity and rise in Na-K-ATPase activity, associated with the ontogeny, were similar in the control and refed groups, the rise in sucrase activity lagged behind controls in the malnourished-refed group. Jejunal and ileal sucrase activities were still depressed in the malnourished-refed group at $35 \mathrm{~d}$. However, with an additional $7 \mathrm{~d}$ of refeeding, sucrase activity also recovered to control levels.

The enhanced net $\mathrm{Na}^{+}$absorption seen in the ileum of all malnourished animals persisted in the refed group for the first 4 days of refeeding. However as the duration of refeeding increased, glucose-stimulated $\mathrm{Na}^{+}$absorption returned to control levels. The mechanisms responsible for this down-regulation of transport remain to be defined.

The findings in this study indicate that the alterations of intestinal growth, development, and function caused by severe postnatal protein-energy malnutrition are rapidly reversable with nutritional repletion. A brief period of refeeding leads to complete recovery of intestinal structure, mucosal mass, epithelial kinetics, and mucosal function in severely malnourished infant rabbits. 
Acknowledgments. The authors thank P. Brockway, G. Curtis, and $K$. van der Lee for expert technical assistance and $G$. Hardy for care devoted to the preparation of the manuscript.

\section{REFERENCES}

1. Chen LC 1983 Interactions of diarrhea and malnutrition. In: Chen LC Scrimshaw NS (eds) Diarrhea and Malnutrition. Plenum Press, New York, pp 3-19

2. Vyas D, Chandra RK 1985 Effects of nutritional deficiency. In: Booth CG, Neale G (eds) Disorders of the Small Intestine. Blackwell, Oxford, pp 299310

3. Brunser O 1975 Effects of malnutrition on intestinal structure and function in children. Clin Gastroenterol 6:341-352

4. Cook GC, Lee FD 1966 The jejunum after Kwashiorkor. Lancet 2:1263-1267

5. Bowie MD, Barbezat GO, Hansen JDL 1967 Carbohydrate absorption in malnourished children. Am J Clin Nutr 20:89-97

6. Altmann GG 1972 Influence of starvation and refeeding on mucosal size and epithelial renewal in the rat small intestine. Am J Anat 133:391-400

7. Aldewachi HS, Wright NA, Appleton DR, Watson AJ 1975 The effect of starvation and refeeding on cell population kinetics in the rat small bowel mucosa. J Anat 119:105-121

8. Solimano G, Burgess EA, Levin B 1967 Protein-calorie malnutrition: effect of deficient diets on enzyme levels of jejunal mucosa of rats. Br J Nutr 21:5568

9. Rossi TM, Lee PC, Young CM, Lerner A, Lebenthal E 1986 Effect of nutritional rehabilitation on the development of intestinal brush border disaccharidases of postnatally malnourished weanling rats. Pediatr Res 20:793-797

10. Butzner JD, Gall DG 1988 Impact of protein-calorie malnutrition on the developing intestine. Biol Neonate 54:151-159

11. Butzner JD, Gall DG 1988 Effects of chronic protein-calorie malnutrition on small intestinal repair after an acute bacterial enteritis: A study in infant rabbits. Pediatr Res 23:408-413
12. Dalqvist A 1968 Assay of intestinal disaccharidases. Anal Biochem 22:99-107

13. Kelly M, Butler DG, Hamilton JR 1972 Transmissible gastroenteritis in piglets: a model of infantile viral diarrhea. J Pediatr 80:925-931

14. Lowry OH, Rosenbrough NJ, Farr AL, Randall RJ 1951 Protein measurement with the folin phenol reagent. J Biol Chem 193:265-275

15. Hinegardner R 1971 An improved fluorometric assay for DNA. Anal Biochem 39:197-201

16. Shepherd R, Hamilton JR, Gall DG 1980 The postnatal development of sodium transport in the proximal small intestine of the rabbit. Pediatr Res $14: 250-253$

17. Clarkson TW, Toole SR 1964 Measurement of short-circuit current and ion transport across the ileum. Am J Physiol 206:658-668

18. Wynford-Thomas D, Williams ED 1986 Use of bromodeoxyuridine for cell kinetic studies in intact animals. Cell Tissue Kinet 19:179-182

19. Torun B, Viteri FE 1988 Protein-energy malnutrition. In: Shils ME, Young UR (eds) Modern Nutrition in Health and Disease. Lea \& Febiger, Philadelphia, pp 746-773

20. Guiraldes E, Hamilton JR 1981 Effect of chronic malnutrition on intestinal structure, epithelial renewal and enzymes in suckling rats. Pediatr Res 15:930-934

21. Hatch TF, Leventhal E, Branski D, Kransner J 1979 The effect of early postnatal acquired malnutrition on intestinal growth, disaccharidases and enterokinase. J Nutr 109:1874-1879

22. Henning SJ 1987 Functional development of the gastrointestinal tract. In Johnson LR (ed) Physiology of the Gastrointestinal Tract, 2nd ed. Raven Press, New York, pp 285-300

23. Butzner JD, Butler DG, Miniats OP, Hamilton JR 1985 Impact of chronic protein-calorie malnutrition on small intestinal repair after acute viral enteritis: a study in gnotobiotic piglets. Pediatr Res 19:476-481

24. Marciani P, Lindi C, Faelli A, Esposito G 1987 Effects of semistarvation on transintestinal D-glucose transport and D-glucose uptake in brush border and basolateral membranes of rat enterocytes. Pflugers Arch 408:220-223

25. Goodlad RA, Plumb JA, Wright NA 1988 Epithelial cell proliferation and intestinal absorptive function during starvation and refeeding in the rat. Clin Sci 74:301-306 